\title{
Experiments on Submerged Slope Erosion under Unsteady Water Head
}

\author{
LIANG Xin, XIE Liquan \& ZHU Yehui \\ College of Civil Engineering, Tongji University, 1239 Siping Road, Shanghai, P.R.CHINA
}

\begin{abstract}
The unsteady property of seepage among the slope soil may induce higher erosion. The research results which were carried out by previous scholars were usually based on constant water head while the slope erosion under unsteady water head has not been specially studied. A new setup was proposed in this paper to study the submerged slope erosion under unsteady water head. Using the proposed setup, a series of tests were conducted by contrasting slope erosion conditions with constant water head and with unsteady water head. These tests were purposed to represent the scouring process of unsteady slope soil detachment under periodic upward seepage loading, and to reveal the mechanism of periodic seepage on slope erosion. The measurements focused on the changing profiles of unsteady slope soil and threw light on the details of different seepage conditions, particularly with respect to terrains of seepage formation during the tests. According to the experimental analysis in different seepage conditions of water head, performance of the proposed apparatus was confirmed and the results show that periodic upward seepage would accelerate the erosion, and the effects of periodic seepage loading on slope erosion were quantified in detail. The results can be introduced into the theories of slope erosion to consider the effect of periodic upward seepage on slope soil detachment, and be applied in the erosion protection.
\end{abstract}

\section{INSTRUCTIONS}

The interaction between surface and subsurface water plays an important role in a variety of coastal zone processes (e.g. Cartwright et al., 2004a, b; Cartwright and Nielsen, 2001a, b; Isla and Bujalesky, 2005; Nielsen, 1999; Nielsen and Voisey, 1998; Robinson et al., 2006; Turner and Acworth, 2004; Xin et al., 2010). With respect to the erosion mechanism, erosion by seepage primarily features dispersing and suspension of slope soil (Chen, 2000). There have been a lot of studies on seepage erosions. Several numerical and experimental studies have been conducted which consider the exit point location and seepage face formation (e.g. Turner, 1993, 1995; Clement et al., 1994). Reports from Dunne (1990), Howard and McLane's (1988) indicated that the slope soil was moved away from ground at the slope toe by the upward seepage force, causing slope collapse when the support of slope toe disappeared, or even causing serious retreat of slope. Koroglu and Kabdasli (2011) carried out an experimental investigation on the stability of coastal embankments affected by tsunamis. Guo (1999) studied the free boundary problems of seepage flow.

As mentioned above, the researches which were carried out by previous scholars were usually based on constant water head and the slope erosion under unsteady water head has not been specially studied. As a fact, seepage in the porous medium is usually unsteady in the natural system, because of the actions of some factors such as waves, tides. In terms of infiltration erosions under the action of waves, tides and wave fluctuations of water level, some researchers (Mao, Duan, Cai \& Ru, 2004) simplified it as the constant level when conducting related studies. This simplification has been applied in a number of engineering practices. However, the mechanism of erosions caused by unsteady seepage are much more complex than steady seepage erosions. Therefore, it is necessary to study characteristics of fluctuation seepage.

A new, special equipment was applied to study the effect of unsteady seepage on slope soil detachment quantitatively in this paper.

\section{EXPERIMENT SETUP}

The equipment contains of three parts: a soil-box, a set of seepage supplying device and a vibration generator (see Fig.1). The vibration generator is connected with a little block using a rope. The block is submerged half in the water, as shown in Figure 1. As the vibration generator begins vibrating with a constant period, the block would go up and down, causing the water level in seepage supplying device fluctuate. The seepage supplying device is connected with bottom of the soil-box using a water pipe. Water could go into the soil-box through the water pipe 
and form seepage for the sands in the soil-box. The soil-box is made of plexiglass plates so the tests could be definitely observed. The measuring cylinder is connected to the bottom of the soil-box. The soilbox with height of $50 \mathrm{~cm}$, width of $40 \mathrm{~cm}$, length of $50 \mathrm{~cm}$, is set to be an angle of $27^{\circ}$ by a lifting jack, as in the natural system, the interface between soil surface and ground water is generally sloping. Sand gravel was placed on the bed of the soil-box at a depth of $5 \mathrm{~cm}$ and then soil was placed above at a

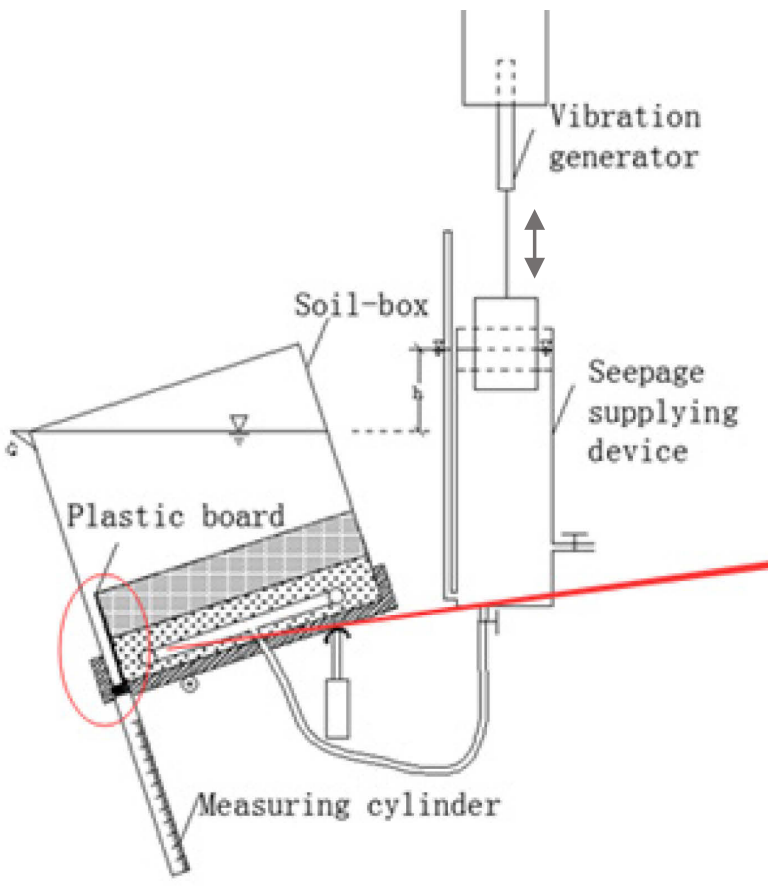

Figure 1. Experimental set-up.

\section{DATA COLLECTION AND DISSCUSSION}

Two contrastive experiments were conducted to study the effect of unsteady seepage water head. The upwards seepage of test 1 showed cascading fluctuation, imitating the actual water level circulation of the sea and tides. In test 2, the water level was set to be steady, to provide comparative experimental analysis. The unsteady water head had a period of 10 minutes, a peak of water level $24 \mathrm{~cm}$ and a valley of $14 \mathrm{~cm}$. The constant water head was set to be $20 \mathrm{~cm}$. In the test, both experiments were carried out for an hour and the erosion volume of sands, $V$, was measured to compare effect of unsteady seepage. Both of the two tests were run for one hour.

After the seepage-induced erosion process, the shapes of two slope terrains were nearly the same with or without unsteady seepage, and the terrains in the fluctuation seepage condition were a little deeper. The toe of the slope and the edge near the soilbox were eroded obviously, as shown in Figure 2(b). We could find out that the damage shape of seepage erosion was in layers. The change of erosion rate and water head in the unsteady seepage condition was depth of $15 \mathrm{~cm}$. Sand particles would climb over the plastic board (as shown in Fig. 1) and drop into the measuring cylinder when erosion occurs. The volume of sands in the cylinder is the erosion volume, $V$. The vertical height difference between the water level in the soil-box and the water level in the seepage supplying device, $h$, is the seepage water head. When water level in the seepage supplying device changes, the water head of seepage fluctuates.

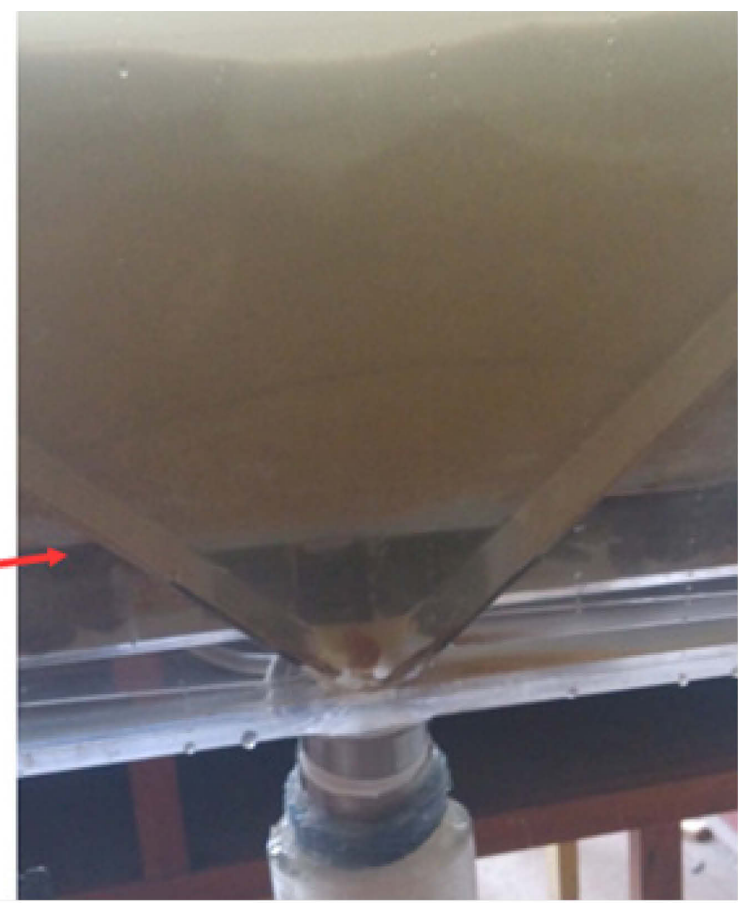

shown in Figure 3. The dot line is water head changes over time. And the continuous line is erosion volume changes over time. Erosion by seepage primarily features dispersing and suspension of slope soil. The seepage flow would carry particles and change soil mass structure. At the same time, the changing of soil structure would cause the permeability coefficient changing (ZHOU, 2009). The erosion rate would increase while the water head became higher, but the erosion rate had a hysteresis quality. For example, when water head became lower, the erosion rate would reduce after a short time, which can be observed in Figure 3. This may be caused by the many factors. With the continuous increase of the upper seepage head, the fine soil sample particles started to move irregularly and randomly. Under a relatively low hydraulic gradient, the small particles in different parts of the sample began moving among the particle spaces, blocking tiny pores in a short time and thereby reducing water permeability of the soil sample. And when seepage head rose, the increasing upwards water force would lift the soil. Thus, when water head becomes higher, seepage goes larger and soil would be easier to slip on the slope and drop into the measuring cylinder.

Figure 4 contrastively shows the erosion rate during the test process, from which we could see the 
significant effect of unsteady seepage on slope soil detachment. The continuous line is erosion volume of sand in the unsteady seepage condition and the dot line is erosion volume for constant seepage. The figure shows that the slope erosion would be accelerated if seepage was fluctuating. The erosion rate was higher with unsteady seepage than with constant seepage when the erosion process began. After about 30 minutes, the erosion volume difference between unsteady seepage and constant seepage became the largest. And as tests went on, the difference became smaller, as shown in Figure 5. This may be caused by the smaller effect of seepage fluctuation when the soil slope angle got smaller.

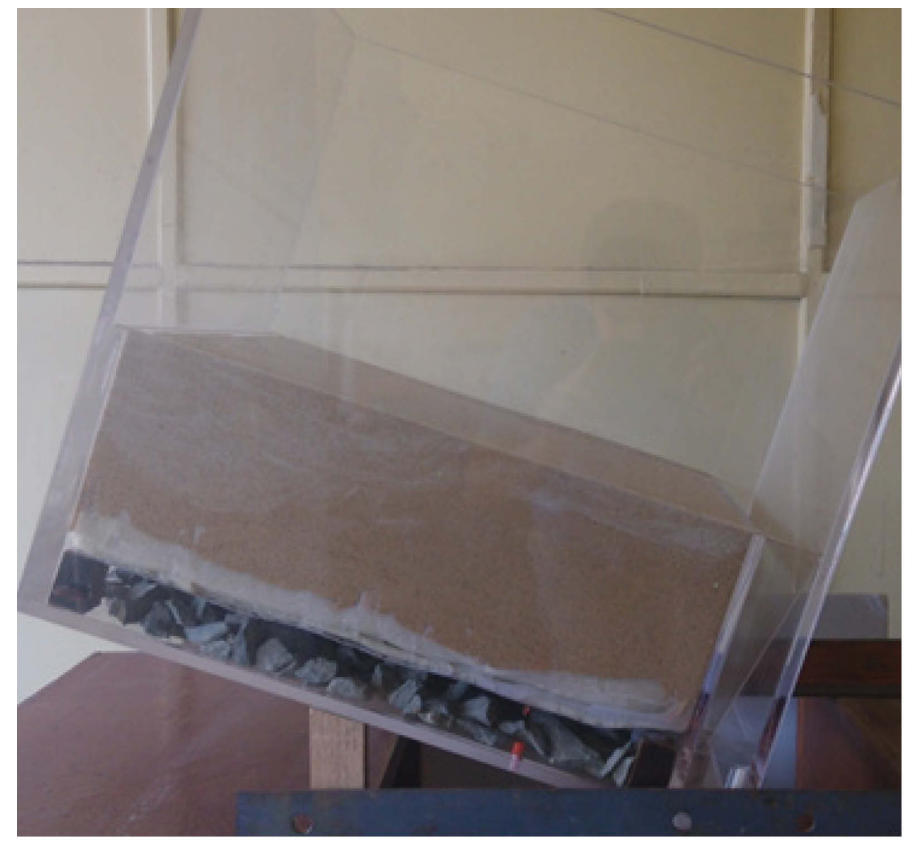

(a) Before the test

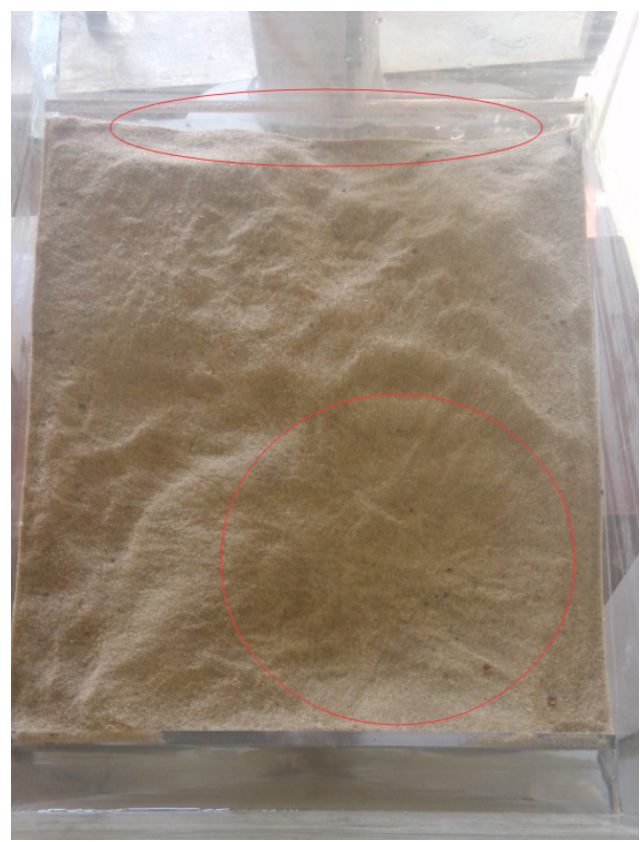

(b) After the test

Figure 2. Contrast of unsteady seepage effect on slope erosion.

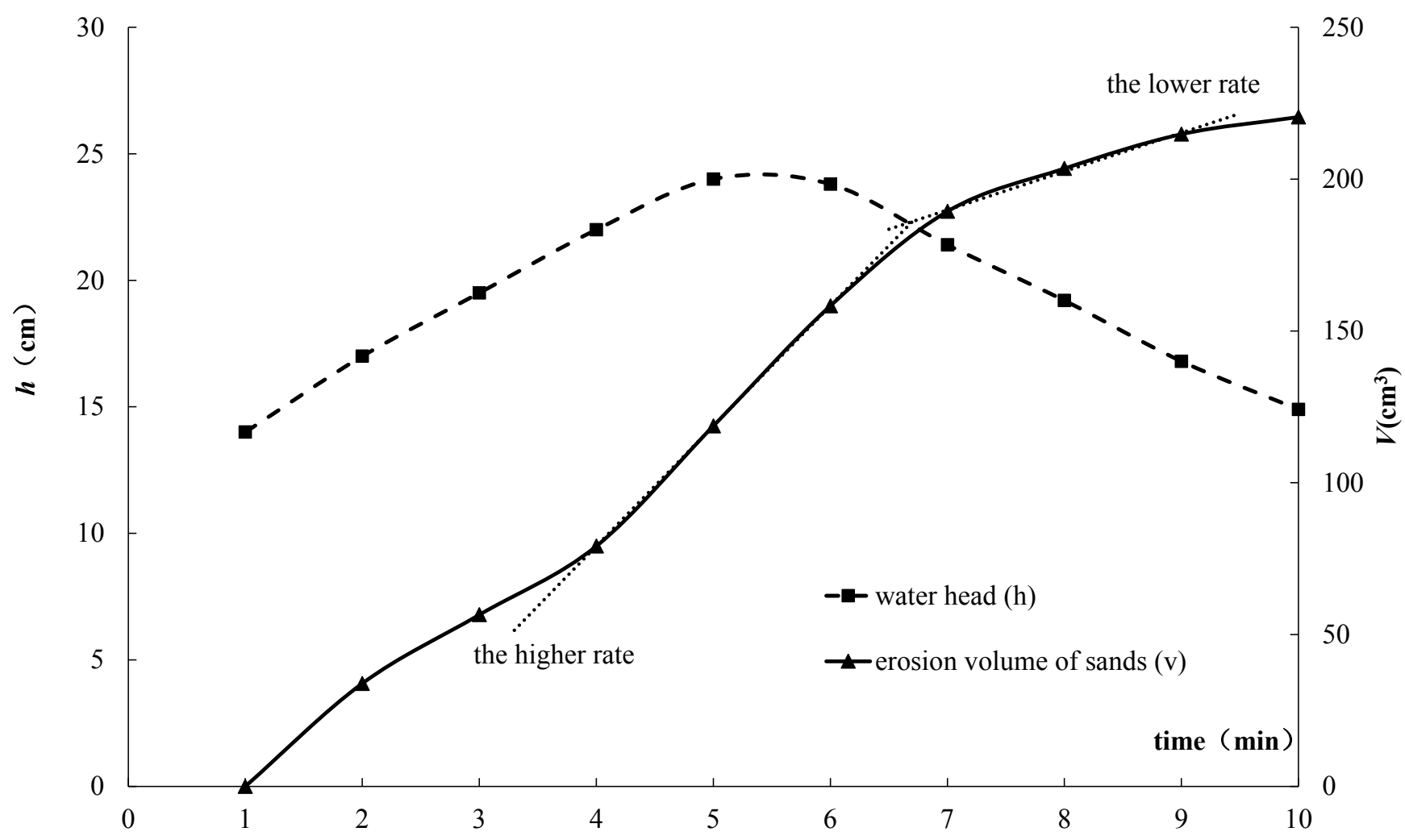

Figure 3. Comparison of erosion volume of sands (with unsteady seepage) and water head. 


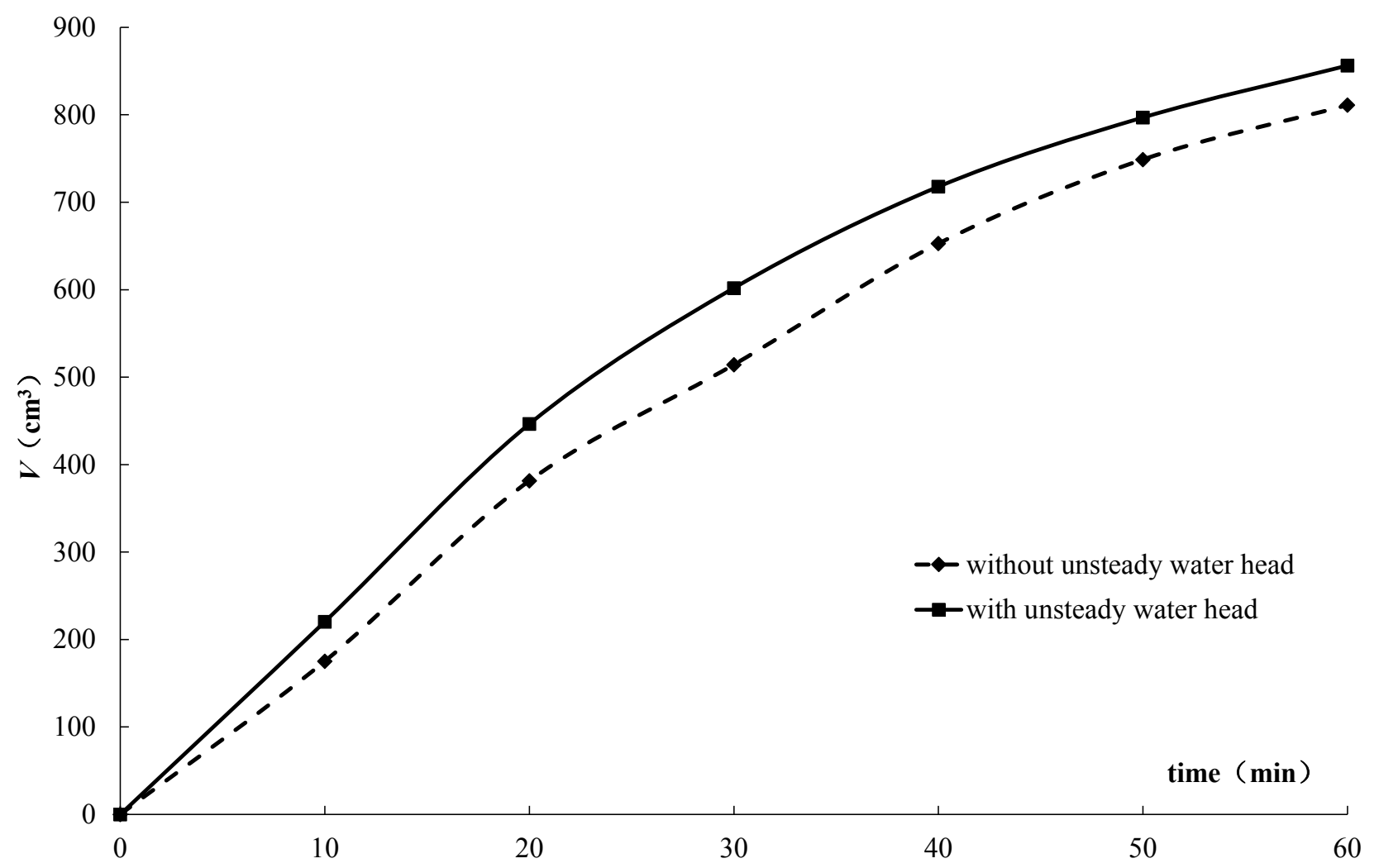

Figure 4. Contrast of unsteady seepage effect on slope erosion.

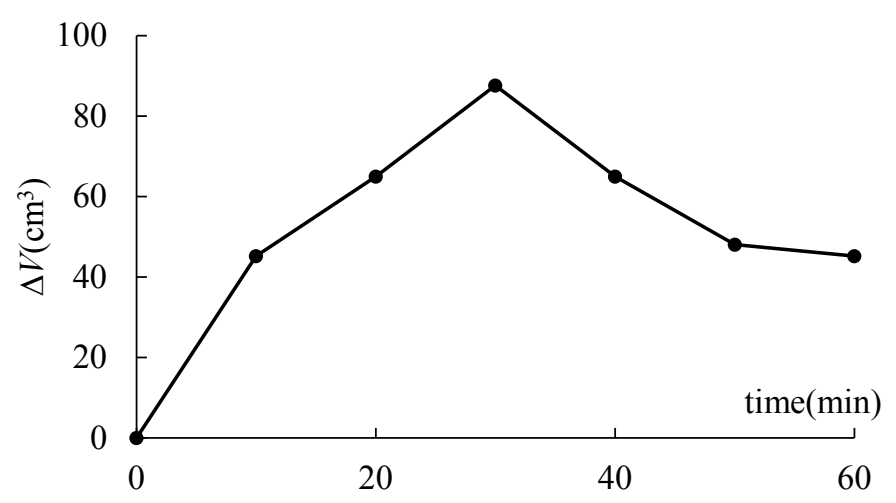

Figure 5. The erosion volume difference between un-steady seepage and constant seepage

Some little pores appeared in the unsteady seepage tests during the scouring process, as shown in Figure 6 . These little holes prove the above analysis considering that the lower seepage would make particles blocking the soil pores and a relatively high hydraulic gradient seepage would increase the uplift force of soil. As a result, the upper soil would be lifted by the seepage and which caused some pores appeared. Because of these little pores, the slope soil became easier to slip down, which made erosion rate higher under the unsteady seepage condition.

\section{CONCLUSION}

The results of this study highlight important similarities and differences of slope soil erosion either with or without unsteady seepage. As far as we know, most of researches have been conducted on erosion by constant seepage. The effect of unsteady seepage on slope erosion has been confirmed qualitatively, but the quantitative study is so difficult to carry out because of lack of corresponding experimental setup that few quantitative results have been published up to now. Based on new experimental techniques of proposed apparatus, the model tests were carried out to study the scouring process of slope soil detachment by unsteady seepage. The following are the conclusions:

(1)The performance of the proposed apparatus and experimental methods was confirmed. This new setup is effective while studying unsteady seepage; 
(2)The results indicated that the effect of unsteady seepage will accelerate the rate of slope erosion and has a serious influence on the stability of slope.

(3) The erosion rate was higher while the water head was higher, but the erosion rate had a hysteresis quality.

\section{ACKNOWLEDGMENTS}

This work was financially supported by the National Natural Science Foundation (No. 11172213).

\section{REFERENCES}

Cartwright, N., Li, L., Nielsen, P., 2004a. Response of the saltfreshwater interface in a coastal aquifer to a wave induced ground-water pulse: field observations and modelling. Water Resource. 27, 297-303.

Cartwright, N., Nielsen, P., Li, L., 2004b. The influence of offshore storm waves on groundwater dynamics and salinity in a sandy beach. In: Proceedings of the 29th International Conference on Coastal Engineering. World Scientific, Singapore, pp. 1841-1850.

Cartwright, N., Nielsen, P., 2001a. Groundwater dynamics and salinity in beaches. In: Proceedings of Coasts and Ports 2001, 15th Australasian Coastal and Ocean Engineering Conference. Gold Coast, Australia, pp. 441-446.

Cartwright, N., Nielsen, P., 2001b. Groundwater dynamics and salinity in coastal barriers. Proc. SWICA-M3, 1st Intl. Conf. on Salt-water Intrusion and Coastal Aquifers-Monitoring, Modelling and Management (Essauira, Morocco), April 2325, CD-ROM.

Chen J., Li X., Zhao W., 2000. Study on piping leakage mechanism. Journal of Hydraulic Engineering, 48-54. (in Chinese)

Clement, T.P., Wise, W.R., Molz, F.J., 1994. A physically based, two-dimensional, finite-difference algorithm for modelling variably saturated flow. J. Hydrol. 161, 71-90.

Guo X., Sun Y., She Y., 1999. Free boundary problem of nonsteady state seepage flow. Communications in Nonlinear Science and Numerical Simulation, 4(1): 43-47.

Isla, F.I., Bujalesky, G.G., 2005. Groundwater dynamics on macro tidal gravel beaches of Tierra del Fuego, Argentina. J. Coast. Res. 21 (1), 65-72.

Koroglu, A., Kabdasli, M. S., 2011. Experimental investigation on the stability of coastal embankments effected by Tsunami. Journal of Coastal Research, 64, 552-556.

Mao, C. X., Duan, X. B., Cai, J. B., \& Ru, J. H., 2004. Experimental study on harmless seepage piping in levee foundation. Journal of Hydraulic Engineering, 11, 46-53.

Nielsen, P., 1999. Groundwater dynamics and salinity in coastal barriers. J. Coastal Res. 15 (3), 732-740.

Robinson, C., Gibbes, B., Li, L., 2006. Driving mechanisms for groundwater flow and salt transport in a subterranean estuary. Ge-ophys. Res. Lett. 33 (3), L03402.

Turner, I.L., 1993. Water table outcropping on macro-tidal beaches: a simulation model. Mar. Geol. 115, 227-238.

Turner, I.L., 1995. Simulating the influence of groundwater seepage on sediment transported by the sweep of the swash zone across the intertidal profile of macro tidal beaches. Mar. Geol. 125, 153-174.

Turner, I.L., Acworth, R.I., 2004. Field measurements of beach face salinity structure using cross-borehole resistivity imaging. J. Coastal Res. 20 (3), 753-760.
Xin, P., Robinson, C., Li, L., Barry, D.A., Bakhtyar, R., 2010. Effects of wave forcing on a subterranean estuary. Water Resource. 46(12), 439-445.

Zhou X., Jie Y., Li G., 2009. Numerical simulation of piping based on coupling seepage and pipe flow. Rock and Soil Mechanics, 30(10): 3154-3158. (in Chinese) 